\title{
Pelayuan Daun pada Padi Lokal Sulut Saat Kekeringan
}

\author{
Evan Jordan Palit a*, Nio Song Ai a, Feky R. Mantiri a
}

aJurusan Biologi, FMIPA, Unsrat, Manado

\begin{tabular}{|c|c|}
\hline KATA KUNCI & A B S T R A K \\
\hline $\begin{array}{l}\text { pelayuan daun } \\
\text { kekeringan } \\
\text { Oryza sativa L. } \\
\text { skor kelayuan }\end{array}$ & $\begin{array}{l}\text { Kekeringan merupakan faktor pembatas utama pada pertumbuhan dan } \\
\text { perkembangan tanaman. Penelitian ini bertujuan untuk mengamati skor } \\
\text { kelayuan pada padi lokal Sulawesi Utara yang diberi cekaman kekeringan. } \\
\text { Penelitian dilaksanakan di rumah kaca di Kelurahan Tingkulu, Manadao, } \\
\text { Sulawesi Utara dari bulan April sampai Mei 2015. Penelitian ini } \\
\text { menggunakan desain Rancangan Acak Lengkap (RAL) dengan } 4 \text { varietas } \\
\text { (Superwin, Ombong, Temo dan Burungan) yang diberikan } 2 \text { perlakuan } \\
\text { pengairan dan } 7 \text { ulangan. Kedua perlakuan pengairan adalah diairi } \\
\text { sampai kapasitas lapang dan tidak diairi selama } 20 \text { hari pada fase } \\
\text { vegetatif tanaman. Skor kelayuan daun (1-9) dapat diamati dan } \\
\text { ditentukan berdasarkan System of Standar Evaluation, IRRI. Penelitian ini } \\
\text { menunjukkan bahwa kekeringan akan memicu pelayuan daun karena } \\
\text { menurunnya potensial air di daun. }\end{array}$ \\
\hline
\end{tabular}

KEYWOR D S

leaf wilting drought Oryza sativa L. wilting score

\begin{abstract}
A B S T R A C T
Drought is a major limiting factor for plant growth and development. Leaf wilting in plant could indicate the drought stress. The objective of this experiment was to identify the leaf wilting score of North Sulawesi local rice cultivars as response to drought. The experiment was conducted in the glasshouse in April to May 2015 at Tingkulu, Manado, North Sulawesi. The experiment was a completely randomized design (CRD) of 4 cultivars (Superwin, Temo, Ombong and Burungan) grown in 2 water regimes, with 1 sampling times and 7 replicates. The two water regimes were wellwatered (WW) and water deficit (WD) obtained by withholding water for 20 days at the vegetative phase. Leaf wilting score (1-9) could be visually determined based on the System of Standar Evaluation in rice by IRRI. The experiment showed that drought periode correlated with the increase of wilting score causes by low water potential.
\end{abstract}

TERSEDIA ONLINE

29 Juli 2015

\section{Pendahuluan}

Air adalah salah satu komponen fisik yang sangat vital dan dibutuhkan dalam jumlah yang besar untuk pertumbuhan dan perkembangan tanaman. Sekitar 85-90\% dari bobot segar sel-sel dan jaringan tanaman adalah air (Maynard dan Orcott, 1987). Fungsi air bagi tanaman adalah sebagai senyawa untuk pembentuk protoplasma, sebagai senyawa pelarut bagi masuknya unsurunsur hara dari larutan tanah ke tanaman dan sebagai pelarut unsur-unsur hara yang akan diangkut dari satu bagian tanaman ke bagian lain, sebagai media terjadinya reaksi-reaksi metabolisme, menjaga turgiditas sel dan sebagai tenaga mekanik dalam pembesaran sel, mengatur mekanisme gerakan tanaman seperti membuka dan menutupnya stomata dan pelipatan daun-daun (Noogle dan Frizt, 1983). Oleh sebab itu pertumbuhan dan perkembangan tanaman akan terhambat jika ketersediaan air tidak memadai.

Air berperan penting dalam proses transportasi dan translokasi unsur hara antar sel dan antar jaringan, pembelahan dan pembesaran sel, serta dalam fotosintesis (Hsiao, 1973). Kekeringan akan

*Corresponding author: Jurusan Biologi FMIPA UNSRAT, Jl. Kampus Unsrat, Manado, Indonesia 95115; Email address: jordanpalit@yahoo.com

Published by FMIPA UNSRAT (2015) 
mempengaruhi berbagai aspek metabolisme dalam tanaman baik secara langsung maupun tidak langsung. Kekeringan dapat menyebabkan penimbunan protein dan toksin, kerusakan biokimia dan inaktivasi enzim, penghambatan pertumbuhan tunas, penyesuaian luas daun, penutupan stomata dan lebih kecilnya ukuran tanaman (Nio dan Banyo, 2011), dan bahkan kematian. Cekaman kekeringan menyebabkan terganggunya keseimbangan proses metabolisme tanaman, termasuk fotosintesis (Sutoro dan Samadiredja, 1989). Penurunan laju fotosintesis mengakibatkan pertumbuhan tanaman terhambat dan terganggu (Arsyad, 2002) dan pada akhirnya akan mengurangi produksi berat kering (Purwanto dan Agustiono, 2010).

Padi (Oryza sativa L.) merupakan tanaman semiakuatik dari suku Poaceae dan telah dijadikan sumber karbohidrat utama oleh sebagian besar penduduk dunia. Padi termasuk dalam genus Oryza yang meliputi kurang lebih 25 spesies, tersebar di daerah tropis dan subtropis, seperti Asia, Afrika, Amerika dan Australia. Tanaman padi termasuk tanaman berumur pendek. Biasanya hanya berumur kurang dari satu tahun (annual) dan berproduksi satu kali. Selain itu, tanaman padi juga merupakan komoditas utama dalam menyokong kebutuhan pangan masyarakat Indonesia karena mampu memenuhi 32\% kebutuhan kalori (Sarwar dan Kanif, 2005; Bouman et al., 2007).

Sebagai negara dengan jumlah penduduk yang besar, Indonesia menghadapi tantangan dalam memenuhi kebutuhan pangan penduduk. Penurunan hasil panen di Indonesia disebabkan oleh berbagai faktor, salah satunya adalah kekeringan (Badan Penelitian dan Pengembangan Pertanian, 2010; Irawati, 2009). Produksi padi nasional, termasuk di Sulawesi Utara mengalami penurunan akibat musim kemarau yang berkepanjangan. Oleh karena itu perlu dilakukan kajian karakter morfologi tajuk khususnya pelayuan daun pada padi lokal Sulawesi Utara dalam upaya untuk mencari varietas unggul yang tahan terhadap kekeringan.

\section{Bahan dan Metode}

Penelitian ini dilaksanakan pada bulan April sampai Mei 2015 selama 8 minggu di rumah kaca di Kelurahan Tingkulu, Manado, Sulawesi Utara dan Laboratorium Ekologi Jurusan Biologi FMIPA Universitas Sam Ratulangi. Bahan yang digunakan dalam penelitian ini adalah padi varietas Superwin, Ombong, Temo dan Burungan, larutan pemutih komersial, pupuk dan air masak. Alat yang akan digunakan yaitu botol air mineral ukuran $600 \mathrm{ml}$ (24 buah), kantong plastik, ember, gayung, dan timbangan. Tanaman padi ditanam pada media berupa campuran tanah taman, pupuk kandang dan sekam dengan perbandingan 5:1:1 serta ditambahkan 2 g pupuk urea, 1 g pupuk TSP dan 2 g pupuk KCl untuk tiap $14 \mathrm{~kg}$ media (Hermanasari et al., 2011).
Untuk mengetahui kualitasnya, benih padi direndam selama 2 jam dalam air garam. Benih yang baik adalah benih yang tenggelam di dasar air. Benih tersebut diambil dan disterilisasi dengan menggunakan pemutih komersial $2 \%$ selama 2 menit dengan 7 kali ulangan, kemudian dibilas dengan air masak. Benih yang sudah steril tersebut kemudian dikecambahkan dalam wadah berisi media pasir yang telah disiram air sampai kapasitas lapang selama 4-5 hari. Benih-benih yang telah berkecambah tersebut kemudian dipindahkan ke pot-pot (berupa botol air mineral $600 \mathrm{ml}$ ) yang sudah disediakan. Namun sebelum pemindahan, tiap pot yang telah berisi tanah disiram dengan air sampai kapasitas lapang (Nio dan Ludong, 2013; Torey, 2013). Tiap pot ditanami 1 benih yang telah berkecambah, selanjutnya disiram dengan campuran air dan pupuk (10 g pupuk Gandasil D dalam $10 \mathrm{~L}$ air) sampai kapasitas lapang. Setiap 2 hari tanaman terus disiram sampai kapasitas lapang sampai mencapai tahap 2 daun yang berkembang penuh (2 fully expanded leaf), dan perlakuan dimulai. Data skor kelayuan daun diperoleh secara visual dengan mengamati penampakan daun dan dibandingkan dengan skor yang telah tercantum dalam IRRI (2002). Data yang diperoleh akan dianalisis dengan ANAVA. Jika ada perbedaan yang nyata, maka akan dilanjutkan dengan uji BNT 5\% untuk menunjukkan ada tidaknya perbedaan yang signifikan.

\section{Hasil dan Pembahasan}

Tanaman yang mengalami kekeringan tidak memperoleh pasokan air yang cukup untuk pertumbuhan dan perkembangannya. Pada kondisi kekeringan sel tanaman akan mengalami kehilangan turgor untuk membuka dan menutupnya stomata serta laju perluasan daun yang sangat bergantung pada tekanan turgor akan menurun (Lestari, 2006; Kramer, 1980). Tanaman yang terus mendapat cekaman kekeringan akan terlihat layu karena menurunnya potensial air di daun.

Padi varietas Superwin menunjukkan respons yang cepat terhadap cekaman kekeringan pada hari ke-3 perlakuan dengan rata-rata skor kelayuan 1,0 lebih tinggi dibandingkan varietas Temo $(0,86)$, Ombong $(0,71)$ dan Burungan $(0,71)$ meskipun tidak berbeda nyata berdasarkan uji BNT 5\%. Di lain pihak, varietas Burungan yang diairi mempunyai skor kelayuan yang rendah yakni 0,29 dibandingkan dengan ketiga varietas lainnya yang masing-masing menunjukkan rata-rata skor kelayuan 0,71. Pada hari ke-6 pemberian perlakuan mulai terjadi perubahan skor kelayuan meskipun tidak ada perbedaan nyata untuk interaksi antara faktor pengairan dan varietas. Selama hampir 1 minggu diberikan cekaman kekeringan, tingkat kekeringan mencapai skor 3 dimana sebagian besar daun layu sedangkan batang masih segar. Pada hari tersebut rata-rata skor kelayuan untuk tanaman yang tidak diairi lebih besar daripada tanaman yang diairi. 


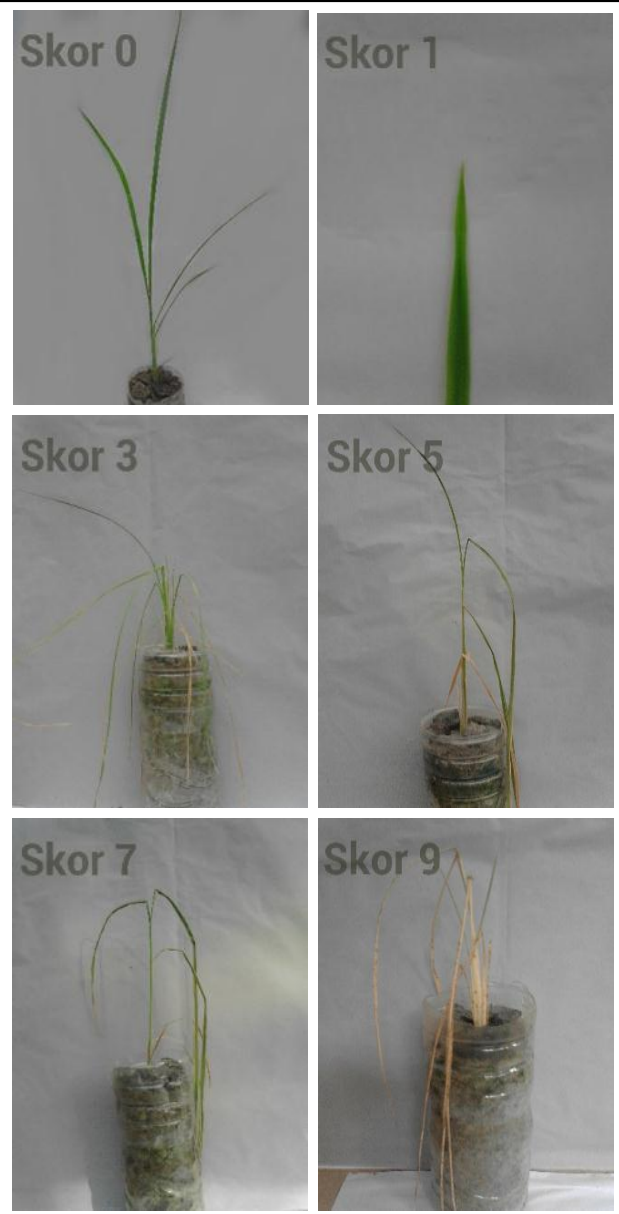

Gambar 1. Skor kelayuan pada empat varietas padi lokal Sulawesi Utara yang diberi perlakuan diari dan tidak diairi selama 20 hari.

Hasil analisis data menunjukkan bahwa skor kelayuan pada hari ke 8, 10, 13 dan 20 berbeda nyata berdasarkan uji BNT 5\%. Hal ini menunjukkan bahwa pada hari ke 8, 10, 13 dan 20 faktor perlakuan yaitu pengairan mempengaruhi aktivitas fisiologis pada tanaman yang mempengaruhi proses pelayuan daun. Pada hari ke-8, tidak ada perbedaan yang nyata antara skor kelayuan pada keempat varietas tanaman yang diberi air. Bahkan keempat varietas masih menunjukkan rata-rata skor kelayuan 1 dimana pelayuan hanya terjadi di bagian tepi daun saja. Di lain pihak, tanaman yang tidak diairi mempunyai skor kelayuan yang lebih tinggi. Padi varietas Superwin mempunyai skor tertinggi yakni 3,57 dan berbeda nyata dengan Temo $(2,14)$, Burungan $(1,51)$ dan Ombong $(1,28)$. Pada hari tersebut, sebagian besar daun pada tanaman yang tidak diairi mulai layu sedangkan batangnya masih segar (skor 3) meskipun banyak juga tanaman yang seluruh daunnya sudah layu (skor 5).

Tanaman yang diberi air tidak mengalami perubahan skor kelayuan pada hari ke-10 pemberian perlakuan dan semua varietas masih menunjukkan rata-rata skor kelayuan 1. Di lain pihak, tanaman yang tidak diairi juga tidak mengalami perubahan skor kelayuan yang nyata meskipun pada varietas Temo terjadi perubahan rata-rata skor kelayuan dari 1,57 menjadi 2,14 dan tidak berbeda nyata dengan Ombong dan Burungan. Rata-rata skor kelayuan keempat varietas tanaman padi yang diairi masih menunjukkan skor 1 bahkan sampai hari ke-13 pemberian perlakuan. Tidak ada perbedaan yang nyata antara keempat varietas berdasarkan interaksi antara faktor pengairan dan varietas. Pada tanaman yang tidak diairi, varietas Ombong menunjukkan skor kelayuan terendah yaitu 1,57 dan berbeda nyata dengan Temo (3), Burungan $(3,28)$ dan Superwin $(3,57)$. Hanya sebagian besar daun pada varietas Ombong yang mengalami pelayuan (skor 3) sedangkan pada ketiga varietas lainnya yaitu Temo, Burungan dan Superwin, semua daun pada tanaman sudah mengalami pelayuan meskipun batangnya masih terlihat segar (skor 5).

Tabel 1. Skor Kelayuan padi varietas Superwin, Ombong, Temo dan Burungan yang diairi sampai kapasitas lapang (DA) dan tidak diairi (TA) selama 20 hari (rata-rata \pm standar error).

\begin{tabular}{ccccccccc}
\hline \multirow{2}{*}{$\begin{array}{c}\text { Hari } \\
\text { ke- }\end{array}$} & \multicolumn{2}{c}{ Superwin } & \multicolumn{2}{c}{ Ombong } & \multicolumn{2}{c}{ Temo } & \multicolumn{2}{c}{ Burungan } \\
\cline { 2 - 9 } & DA & TA & DA & TA & DA & TA & DA & TA \\
\hline 0 & $0 \pm 0$ & $0 \pm 0$ & $0 \pm 0$ & $0 \pm 0$ & $0 \pm 0$ & $0 \pm 0$ & $0 \pm 0$ & $0 \pm 0$ \\
1 & $0 \pm 0$ & $0 \pm 0$ & $0 \pm 0$ & $0 \pm 0$ & $0 \pm 0$ & $0 \pm 0$ & $0 \pm 0$ & $0 \pm 0$ \\
3 & $0,71 \pm 0,18$ & $1 \pm 0$ & $0,71 \pm 0,18$ & $0,71 \pm 0,18$ & $0,71 \pm 0,18$ & $0,86 \pm 0,14$ & $0,29 \pm 0,18$ & $0,71 \pm 0,18$ \\
6 & $1 \pm 0$ & $1,57 \pm 0,37$ & $0,71 \pm 0,18$ & $1 \pm 0,14$ & $0,86 \pm 0,14$ & $1,29 \pm 0,29$ & $1 \pm 0,18$ & $0,86 \pm 0,38$ \\
8 & $1 \pm 0 a$ & $3,57 \pm 0,57 \mathrm{c}$ & $1 \pm 0 \mathrm{a}$ & $1,57 \pm 0,29 \mathrm{ab}$ & $1 \pm 0 \mathrm{a}$ & $2,14 \pm 0,4 \mathrm{~b}$ & $1 \pm 0 \mathrm{a}$ & $1,29 \pm 0,37 \mathrm{a}$ \\
10 & $1 \pm 0 \mathrm{a}$ & $3,57 \pm 0,57 \mathrm{c}$ & $1 \pm 0 \mathrm{a}$ & $2,14 \pm 0,29 \mathrm{~b}$ & $1 \pm 0 \mathrm{a}$ & $2,14 \pm 0,4 \mathrm{~b}$ & $1 \pm 0 \mathrm{a}$ & $1,29 \pm 0,4 \mathrm{ab}$ \\
13 & $1 \pm 0 \mathrm{a}$ & $3,57 \pm 0,57 \mathrm{~b}$ & $1 \pm 0 \mathrm{a}$ & $3,29 \pm 0,37 \mathrm{~b}$ & $1 \pm 0 \mathrm{a}$ & $3 \pm 0,44 \mathrm{~b}$ & $1 \pm 0 \mathrm{a}$ & $1,57 \pm 0,52 \mathrm{a}$ \\
15 & $1 \pm 0$ & $4,43 \pm 0,72$ & $1 \pm 0$ & $4,71 \pm 0,62$ & $1 \pm 0$ & $4,71 \pm 0,52$ & $1 \pm 0$ & $3 \pm 0,52$ \\
17 & $1 \pm 0$ & $5 \pm 0,76$ & $1 \pm 0$ & $5,29 \pm 0,57$ & $1 \pm 0$ & $5 \pm 0,76$ & $1 \pm 0$ & $3,57 \pm 0,52$ \\
20 & $1 \pm 0 \mathrm{a}$ & $5,86 \pm 0,59 \mathrm{c}$ & $1 \pm 0 \mathrm{a}$ & $6,43 \pm 0,4 \mathrm{c}$ & $1,29 \pm 0,29 \mathrm{a}$ & $6,71 \pm 0,52 \mathrm{c}$ & $1 \pm 0 \mathrm{a}$ & $4,14 \pm 0,57 \mathrm{~b}$ \\
\hline
\end{tabular}


Berdasarkan uji BNT 5\%, tidak ada perbedaan nyata pada skor kelayuan keempat varietas yang diairi pada hari ke-20 yang merupakan hari terakhir pemberian perlakuan. Pada hari tersebut, tanaman yang diairi masih bertumbuh dengan baik dengan rata-rata skor kelayuan berkisar antara 1 sampai 1,29. Varietas Superwin, Temo, Ombong dan Burungan yang diairi tidak menunjukkan perbedaan yang nyata, karena keempat varietas masih menerima suplai air yang cukup untuk aktivitas metabolismenya meskipun pelayuan tetap terjadi tetapi hanya di bagian tepi daun (Tabel 1). Di lain pihak, pada tanaman yang tidak diairi, varietas Burungan menunjukkan rata-rata skor kelayuan terendah yakni 4,14 dan berbeda nyata dengan ketiga varietas lainnya yaitu Superwin $(5,86)$, Ombong $(6,43)$ dan Temo $(6,71)$. Pada hari tersebut, semua daun pada tanaman yang tidak diberi air sudah mengalami pelayuan dan bagian atas batang mulai mengering (skor 7 ) bahkan ada tanaman yang mati (skor 9).

Tanaman yang bisa mempertahankan potensial airnya meskipun dalam cekaman kekeringan, ditunjukkan dengan memiliki skor kelayuan yang rendah. Tanaman dengan kondisi tersebut bisa dikatakan sebagai tanaman yang tahan terhadap kekeringan. Skor kelayuan menunjukkan tingkat respons tanaman terhadap kekeringan akibat kekurangan air. Secara umum skor kelayuan pada varietas padi yang diairi lebih kecil daripada yang tidak diairi.

\section{Kesimpulan}

Skor kelayuan dapat dipakai sebagai indikator tahan kering pada keempat varietas padi lokal Sulawesi Utara. Tanaman yang tidak diairi menunjukkan skor kelayuan yang lebih tinggi daripada tanaman yang diberi pengairan. Padi pada keempat varietas yang diairi memiliki skor kelayuan yang tidak berbeda nyata satu sama lain dengan rata-rata skor kelayuan 1 sampai 1,29 Di lain pihak, pada tanaman yang tidak diairi, varietas Burungan menunjukkan rata-rata skor kelayuan terendah yakni 4,14 dan berbeda nyata dengan ketiga varietas lainnya yaitu Superwin $(5,86)$, Ombong $(6,43)$ dan Temo $(6,71)$. Berdasarkan skor kelayuan, padi varietas Burungan menunjukkan kemampuannya dalam mempertahankan potensial airnya sehingga memenuhi kriteria sebagai padi tahan kering dan berpotensi untuk ditanam pada saat musim kemarau.

\section{Daftar Pustaka}

Arsyad, A.R. 2002. Kemampuan Adaptasi Tanaman Kedelai terhadap Kekeringan pada Tanah dengan Tekstur yang Berbeda. Jurnal Agronomi. 8(2):99-103.

Balai Penelitian dan Pengembangan Departemen Pertanian. 2005. Rencana Aksi Pemantapan Ketahanan Pangan 2005-2010. Lima
Komoditas: Beras, Jagung, Kedelai, Gula dan Daging Sapi. Balitbang, Deptan. Jakarta.

Bouman, B.A.M., E. Humphreys, T.P Tuong dan R. Barker. 2007. Rice and Water. Adv. Agron. 92:187-237.

Fitter, A.H. dan R.K.M Hay. 1991. Fisiologi Lingkungan Tanaman. Gadjah Mada University Press. Yogyakarta.

Hermanasari, R., Supartopo, A. Hairmansis, Yullianida dan B. Kustianto. 2011. Galur Harapan Padi Rawa Toleran Rendaman. Penelitian Pertanian Tanaman Pangan. 30(2):71-75.

Hsiao, T.C. 1973. Plant Responses to Water Stress. Plant Physiol 24:519-570.

Irawati, N. 2009. Analisis Sikap dan Kepuasan Petani Padi terhadap Benih Padi (Oryza sativa L.) Varietas Unggul di Kota Solok, Sumatera Barat [Skripsi]. Fakultas Ekonomi dan Manajemen IPB. Bogor.

IRRI. 2002. Standard Evaluation System for Rice (SES). International Rice Research Institute Los Banos. Filipina.

Kramer, P.J. 1980. Plant and Soil-Water Relationship. McGraw-Hill Book Company, Inc. New York.

Lenak, A.A. 2014. Penggulungan Daun dan Alokasi Biomassa pada Padi Lokal Sulut saat Kekurangan Air [Skripsi]. FMIPA Universitas Sam Ratulangi. Manado.

Lestari, E.G. 2006. Hubungan antara Kerapatan Stomata dengan Ketahanan Kekeringan pada Somaklon Padi Gajahmungkur, Towuti, dan IR 64. Biodiversitas. 7(1):44-48.

Maynard, G.H dan D.M Orcott. 1987. The Physiology of Plants under Stress. John Willey and Sons, Inc. New York.

Nio, S.A., A.H Siregar dan S.N Widyanto. 1997. Aktivitas Peroksidase pada Lini Kalus Padi (Oryza sativa L.) Toleran Kekeringan. Eugenia XIII. 3(3):102-108.

Nio, S.A dan Y. Banyo. 2011. Konsentrasi Klorofil Daun sebagai Indikator Kekurangan Air pada Tanaman. Jurnal Ilmiah Sains. 2(2):165-173.

Nio, S.A dan D.P.M Ludong. 2013. Comparing the Drought Tolerance of Local Rice Cultivar Superwin with Other Cultivars Cultivated in North Sulawesi Province Based on Dry Matter Partitioning. $4^{\text {th }}$ International Converence of Global Resource Conservation. Brawijaya University

Nio, S.A dan Y. Banyo. 2011. Konsentrasi Klorofil Daun sebagai Indikator Kekurangan Air pada Tanaman. Jurnal IImiah Sains. 2(2):165-173.

Noogle, G.R dan G.J Fritz. 1983. Introductory Plant Physiology. Prentice Hall, Inc. New Jersey.

Prihastanti, E. 2010. Kandungan Klorofil dan Pertumbuhan Semai Kakao (Theobroma cacao L.) pada Perlakuan Kekurangan Air yang Berbeda. BIOMA. 12(2): 35-39.

Prihastanti, E. 2011. Specific Leaf Area, Jumlah Trikomata dan Kandungan Kalium Daun Semai 
Kakao (Theobroma cacao L.) pada Kandungan Air Tanah Berbeda. BIOMA. 13(2):85-90.

Purwanto dan T. Agustiono. 2010. Kajian Fisiologi Tanaman Kedelai pada Berbagai Kepadatan Gulma Teki dalam Kondisi Cekaman Kekeringan. Jurnal Agroland. 17(2):85-90.

Sarwar, M.J dan Y.M Kanif. 2005. Low Water Rice Production and Its Effect on Redox Potential and Soil pH. Agron. J. 4:142-146.
Sasmitamihardja, D. dan A. Siregar. 1996. Fisiologi Tumbuhan. Depdiknas. Jakarta.

Sutoro, I. dan Samadiredja. 1989. Reaksi Pemuliaan Tanaman Jagung dan Sorghum pada Fase Pertumbuhan Vegetatif. Penelitian Palawija. 9(4):146-151.

Torey, P. 2013. Karakter Morfologi Akar sebagai Indikator Kekurangan Air pada Padi Varietas Superwin [Skripsi]. FMIPA Universitas Sam Ratulangi. Manado. 